\title{
Study by genre approach to issues and problems in linear algebra students studying SMP/S4
}

\author{
Kasour Radouane ${ }^{1,4}$, AchtaichNaceur ${ }^{1}$, NachitBrahim ${ }^{3,4}$, Saidbenkaddour ${ }^{4}$, \\ Abdallah Hariri ${ }^{5}$ and Talbi Mohammed ${ }^{4}$ \\ ${ }^{1}$ Laboratoire d'Analyse, Modélisation et Simulation (LAMS) ), Université Hassan II-Mohammedia, \\ Casablanca, Maroc \\ ${ }^{2}$ Laboratoire de Technologie de l'Information et Modélisation(LTIM), Université Hassan II-Mohammedia, \\ Casablanca, Maroc \\ ${ }^{3}$ Laboratoire d'Algèbre, Analyse et Applications (L3A), Université Hassan II- Mohammedia, Casablanca, \\ Maroc \\ ${ }^{4}$ Observatoire de Recherches en Didactique et Pédagogie Universitaire (ORDIPU), Université Hassan II- \\ Mohammedia, Casablanca, Maroc \\ ${ }^{5}$ Ingénierie Mécanique, Management Industriel et Innovation Faculté des sciences Settat Maroc.
}

\begin{abstract}
Summary: A questionnaire was presented to the students of SMP half four industry to get an idea on what they think of mathematics and especially linear algebra after two years at the Faculty of Sciences Ben M'sik.

Some questions concerning their knowledge at school. Other issues related to the teaching faculty methods. And other questions are to understand the situation of the student as a genre and level mathematics in high school. The responses are compiled in tables and analyzed to try to get maximum information possible. This is intended to improve efforts to achieve a quality education.

Résumé: Un questionnaire a été présenté aux étudiants de la filière SMP semestre quatre pour avoir une idée sur ce qu'ils pensent des mathématiques et en particulier en algèbre linéaire après deux années passées à la faculté des sciences Ben M'sik.

Certaines questions concernent leurs connaissances au lycée. D'autres questions sont en rapport avec les méthodes d'enseignement à la faculté. Et d'autres questions sont posées pour comprendre la situation de l'étudiant en tant que genre et son niveau en mathématiques au lycée. Les réponses obtenues sont dressées dans des tableaux et analysées pour essayer d'obtenir un maximum d'informations possibles. Ceci dans le but d'améliorer les efforts fournis pour atteindre un enseignement de qualité.
\end{abstract}

Keywords:genre, linear algebra, obstacle, knowledge, teaching methods.

\section{Introduction}

Although since the mid eighty years, the work of teaching are interested in linear algebra, they generally concern only the basics of the field of mathematics (Dorier 1997; Trigueros, 2005).

In our article presented here, we try at first to identify students as Genre, for a gender approach and see the influence of gender on the obstacles and difficulties that may have students in algebra linear, in order to provide recommendations to overcome these obstacles and difficulties.

Then interpret the obstacles and difficulties encountered in linear algebra, which are linked:

$>$ In the knowledge.

$>$ In teaching methods.

$>$ A reformulation of the course.

Our work beyond Gender, also aims to clarify the origin and nature of the obstacles and difficulties of students in linear algebra, the chain SMP/S2.

\section{Problem :}

University professors in the Faculty of Science BEN M'sik found that students have difficulties in "Linear Algebra", while this matter was easy for students of eighty years and ninety.

And this is clear by examining the results of the two generations.

So the questions arise:

What is the cause of lowering the level of the students? And is that the type will affect the learning of linear algebra?

What causes this problem? And how can it be remedied?

Assumptions: 
Maybe pedagogy adopted by each generation is the cause of this reduction. Maybe the nature of matter in general "mathematical" form a formal system based on axioms is not consistent with the pedagogy followed.

\section{1- OBSTACLES :}

\section{Theoretical Framework :}

Brousseau and analyzes the role of errors: "The error and failure are not simplified role is sometimes want them to play The error is not only the effect of ignorance,. uncertainty, the chance that one believes in empirical and behavioral theories of learning, but the effect of prior knowledge, which had its interest, its success, but is now found false, or simply inadequate . Errors of this type are not erratic and unpredictable, they are constituted obstacles. Both in the operation of the master than in the student, the error is constitutive of the meaning of the acquired knowledge. "(Brousseau 1983, 171).

\section{2- KNOWLEDGEANDLOCATION:}

Knowledge is the result of an adaptation of the stands at a situation S which "justifies" this knowledge by making it more or less effective, different knowledge leading to learning and executions of tasks with different complexities. Following values of the relevant variables of S, we can imagine that we associate with each useful knowledge in S, surface effectiveness (or cost). The upper envelope of these surfaces can spare the maximum, separated by necks (or any other singularity).

So to create the student some knowledge, the teacher "must" choose the optimal values that make this knowledge in relation to competing knowledge must then grow by leaps and not on a regular basis: For example, if we want to promote the solution of a linear by linear combinations, for students who know the method substitution system, it is better to choose systems that rank 42 or even 3

\section{Descriptionofthesurvey:}

The questionnaire was distributed to 250 students in four half SMP sector, this population is more than $25 \%$ of students of the Faculty of Science Ben M'sik, Hassan II Casablanca, and 222 questionnaires were recovered, so we can say that the workforce is very important for this investigation, and also we have a majority of $73.3 \%$ of students who took the physical sector - chemistry in high school and that the judgment will be based on this field.

\section{1- GENRE :}

\begin{tabular}{|c|c|c|c|c|c|}
\hline \multicolumn{2}{|c|}{} & workforce & percentage & percentage valid & $\begin{array}{c}\text { percentage } \\
\text { cumulative }\end{array}$ \\
\hline \multirow{3}{*}{ Valid } & male & 99 & $44.6 \%$ & $44.8 \%$ & $44.8 \%$ \\
\cline { 2 - 6 } & female & 122 & $55.0 \%$ & $55.2 \%$ & $100.0 \%$ \\
\cline { 2 - 6 } & Total & 221 & $99.5 \%$ & $100.0 \%$ & \\
\cline { 2 - 6 } & system missing & 1 & $0.5 \%$ & & \\
\hline \multicolumn{2}{|c|}{ Total } & 222 & $100.0 \%$ & & \\
\hline
\end{tabular}

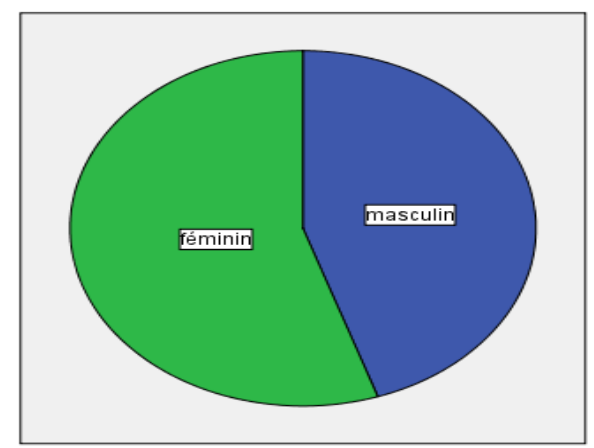

It has 221 students who responded to the question " genre," and only one person who does not respond to this question. 
The female enrollment is 122 , which represents $55.2 \%$ while those of men is $44.8 \%$ and this reflects the reality that exists in high school: that girls outnumber boys.

\section{2- Genre / Student status:}

Processing summary observations

\begin{tabular}{|l|l|l|l|l|l|l|}
\hline & \multicolumn{4}{|l|}{ Observations } & missing & Total \\
\cline { 2 - 7 } & Valid & percentage & $\mathrm{N}$ & percentage & $\mathrm{N}$ & percentage \\
\cline { 2 - 7 } & $\mathrm{N}$ & $86.0 \%$ & 31 & $14.0 \%$ & 222 & $100.0 \%$ \\
\hline Genre / Student status: & 191 & &
\end{tabular}

PivotTable genre / the status of the student

Workforce

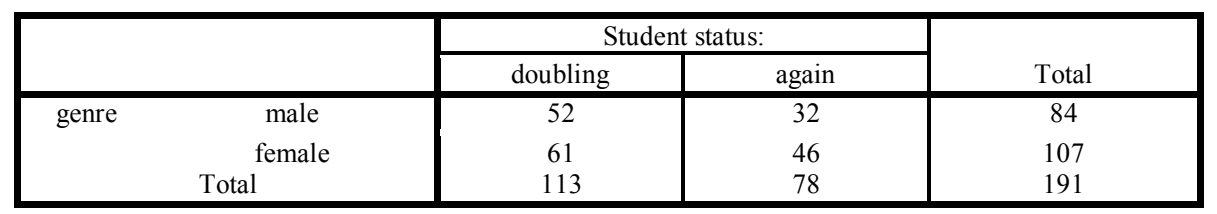

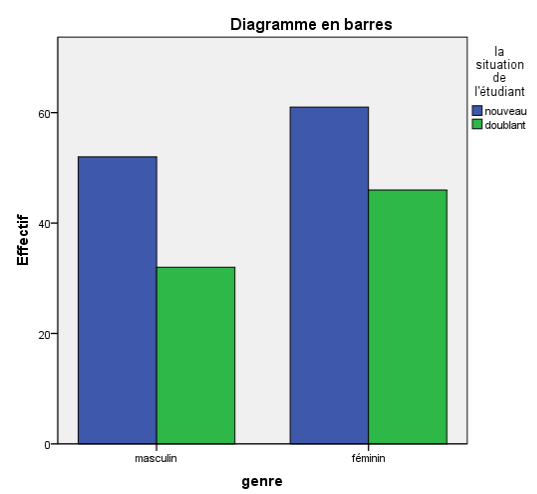

191 students who responded to both questions granny time, a rate of $86.00 \%$, so it has a majority.It was found that the percentage of girls doublers is high compared to the percentage of repeaters boys.

We can say that girls face more difficulties than boys in the industry Physics-Chemistry option.

\section{3- Genre / What is the rating of mathematics in the national examination?}

Processing summary observations

\begin{tabular}{|c|c|c|c|c|c|c|}
\hline & \multicolumn{6}{|c|}{ Observations } \\
\hline & \multicolumn{2}{|c|}{ Valid } & \multicolumn{2}{|c|}{ missing } & \multicolumn{2}{|c|}{ Total } \\
\hline & $\mathrm{N}$ & percentage & $\mathrm{N}$ & percentage & $\mathrm{N}$ & percentage \\
\hline $\begin{array}{l}\text { Genre / What is the rating of } \\
\text { mathematics in the national } \\
\text { examination? }\end{array}$ & 216 & $97.3 \%$ & 6 & $2.7 \%$ & 222 & $100.0 \%$ \\
\hline
\end{tabular}

PivotTable * what kind note of mathematics in the national examination?

Workforce

\begin{tabular}{|lc|r|r|r|r|r|}
\hline & \multicolumn{5}{|c|}{ what kind note of mathematics in the national examination? } & \\
\cline { 2 - 6 } & & & between $8 / 20$ and & between $13 / 20$ and \\
& & & $16 / 20$ & & \\
Tess than $7 / 20$ & & more than $17 / 20$ & Total \\
\hline genre & male & 8 & 28 & 43 & 16 & 95 \\
& female & 9 & 44 & 55 & 13 & 121 \\
Total & & 72 & 98 & 29 & 216 \\
\hline
\end{tabular}




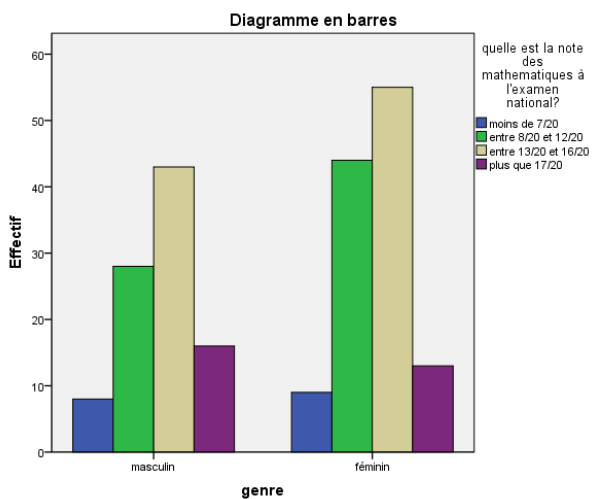

It has 216 students who have validated the two questions at the same time, and this is represented by a percentage of $97.30 \%$, which is an absolute majority.

The remark that can be drawn is that the number of boys who have less than 07/20 is lower than that of girls, while the number of boys who have more than 17/20 is greater than that of girls.

And for this we can conclude that boys high school math mastered better than girls.

\section{4- Genre / BAC What did you get?}

Processing summary observations

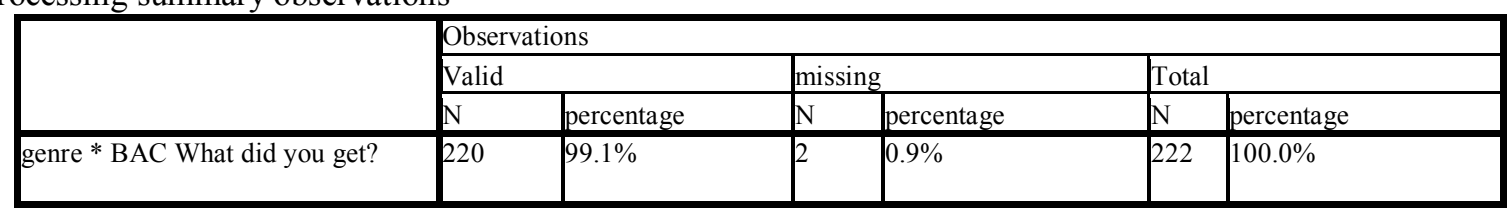

PivotTable kind / BAC what did you get?

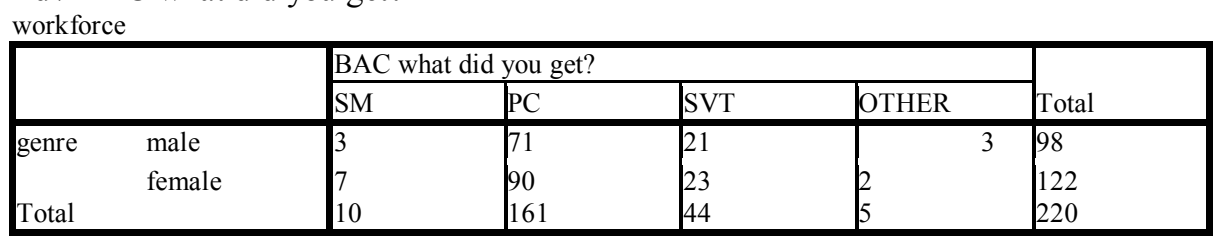

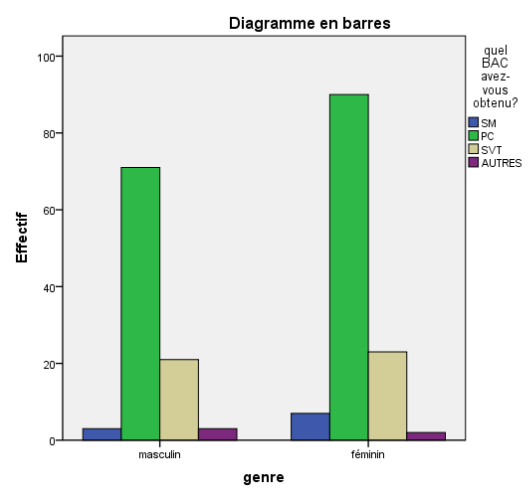

It has 220 students who have validated the two questions at the same time, a rate of $99.10 \%$, so there are two students who did not respond to two successive issues, a rate of $00.90 \%$.

Girls represent $05.7 \%$ who have their bachelor mathematical sciences, while $03.1 \%$ of boys in this industry. While the percentages of girls and boys respectively $73.78 \%$ and $72.45 \%$ in the entire population of the survey for the science branch physics and chemistry among 122 girls and 98 boys.

So we have the same representation of boys and girls in this industry, and for this we can say that the character "Genre" is broken. 
5- Genre / problems and difficulties encountered in linear algebra are related:

Processing summary observations

\begin{tabular}{|c|c|c|c|c|c|c|}
\hline & \multicolumn{6}{|c|}{ Observations } \\
\hline & \multicolumn{2}{|c|}{ Valid } & \multicolumn{2}{|c|}{ missing } & \multicolumn{2}{|c|}{ Total } \\
\hline & $\mathrm{N}$ & percentage & $\mathrm{N}$ & percentage & $\mathrm{N}$ & percentage \\
\hline $\begin{array}{l}\text { Genre / problems and difficulties } \\
\text { encountered in linear algebra are } \\
\text { related }\end{array}$ & 136 & $61.3 \%$ & 86 & $38.7 \%$ & 222 & $100.0 \%$ \\
\hline
\end{tabular}

Crosstab Genre * problems and difficulties encountered in linear algebra are related:

\begin{tabular}{|c|c|c|c|c|c|c|}
\hline & & \multicolumn{4}{|c|}{ problems and difficulties encountered in linear algebra are related } & \multirow[b]{2}{*}{ Total } \\
\hline & & knowledge & teaching methods & $\begin{array}{l}\text { the formulation of the } \\
\text { course }\end{array}$ & 5 & \\
\hline & male & 6 & 40 & 16 & 1 & 63 \\
\hline & female & 11 & 41 & 21 & 0 & 73 \\
\hline Total & & 17 & 81 & 37 & 1 & 136 \\
\hline
\end{tabular}

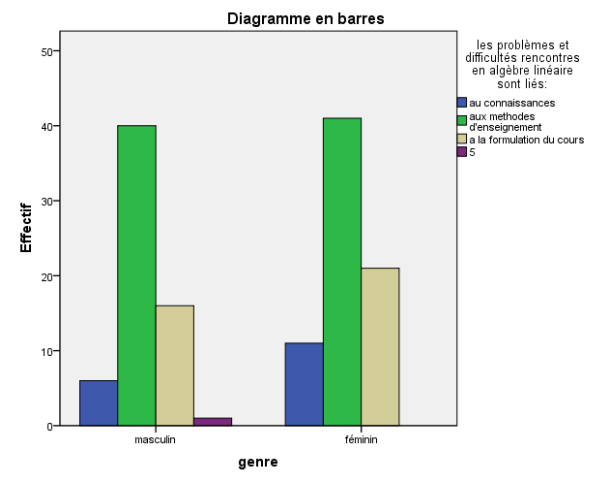

It has 136 students, a rate of $61,30 \%$, which validated both qestions simultaneously.

While 86 students a rate of $38.70 \%$, which did not respond to two questions in time is an important strength, although still a $61.30 \%$ rate.

It has six boys of 63 or $09.52 \%$ boys and 11 girls of 73 girls is $15.05 \%$ and see that the problems encountered in linear algebra difficulés are associated with "knowledge."

Was that girls face problems in linear algebra and difficulés levels of knowledge than boys

And was 40 boys of 63 boys is $63.50 \%$ and 56.16 is 41 filles on 73 filles\% believe that difficulés and problems in linear algebra are associated with "teaching methods".

Was that $59.56 \%$ of students attribute the problems in linear algebra and difficulés "teaching methods", and this percentage is higher, but in regard to the character "Genre" the percentage of boys is higher than girls.

Were 16 boys of 63 boys is $25.40 \%$ and 21 filles of 73 girls is $28.77 \%$ believe that difficulés and problems in linear algebra are related "to the development of the course."

And has 37 students out of 136 or $27.21 \%$ who believe that difficulés and problems in linear algebra are related "to the development of the course."

So it was almost the same percentage of girls and boys that connect and difficulés problems in linear algebra "in the formulation of the course."

But this figure represents only a quarter of the population chooses.

\section{6- Genre / If knowledge is a problem or difficulty that is due to:}

Processing summary observations

\begin{tabular}{|c|c|c|c|c|c|c|}
\hline \multirow{2}{*}{} & \multicolumn{4}{|c|}{ Observations } \\
\cline { 2 - 7 } & \multicolumn{2}{|c|}{ Valid } & \multicolumn{2}{|c|}{ missing } & \multicolumn{2}{c|}{ Total } \\
\cline { 2 - 7 } & $\mathrm{N}$ & percentage & $\mathrm{N}$ & percentage & $\mathrm{N}$ & percentage \\
\hline $\begin{array}{c}\text { Genre / If knowledge is a problem or } \\
\text { difficulty that is due to: }\end{array}$ & 169 & $76.1 \%$ & 53 & $23.9 \%$ & 222 & $100.0 \%$ \\
\hline
\end{tabular}


Genre / If knowledge is a problem or difficulty that is due to:

\begin{tabular}{|c|c|c|c|c|}
\hline & \multicolumn{3}{|c|}{ If knowledge is a problem or difficulty that is due to: } & \multirow[b]{2}{*}{ Total } \\
\hline & $\begin{array}{c}\text { lack of prerequisite in the } \\
\text { student }\end{array}$ & to linear algebra itself & 3 & \\
\hline $\begin{array}{rr}\text { genre } & \text { male } \\
\text { female } \\
\text { Total }\end{array}$ & $\begin{array}{l}51 \\
41\end{array}$ & $\begin{array}{l}26 \\
50 \\
76\end{array}$ & $\begin{array}{l}0 \\
1 \\
1\end{array}$ & $\begin{array}{c}77 \\
92 \\
169\end{array}$ \\
\hline
\end{tabular}

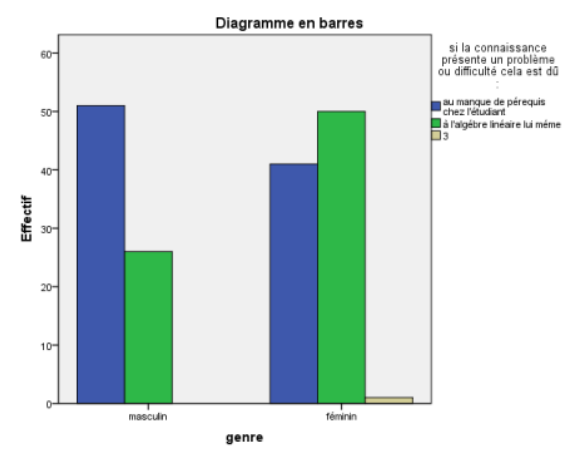

It has 169 students, or $76.10 \%$, which validated the two questions at the same time, while 53 students, $23.90 \%$ who have not validated the two questions, it is a remarkable figure even if $7610 \%$ represents the majority of students who participated in the questionnaire.

Were 51 boys of 77 boys is $66.23 \%$, and 41 girls of 92 girls is $44.57 \%$ ponsent that knowledge has a problem or difficulty because of "lack of prerequisites in the student." The percentage of boys is higher than that of girls.

So we can infer that the lack of prerequisites for boys has a major obstacle to girls. And 26 boys of 77 boys is $33.77 \%$, and 50 girls of 92 girls is $55.48 \%$ believe that knowledge has a problem or difficulty because of because of the algebra itself.

So girls attribute this obstacle to knowledge of algebra itself, and has considerable strength.

In general there is a majority of boys who say that this obstacle is "the lack of prerequisites in the student", that is to say, the boys take their responsibility, while girlsplaintent the linear algebra.

\section{7- Genre / If the teaching of linear algebra approach a problem or difficulty that is due to:}

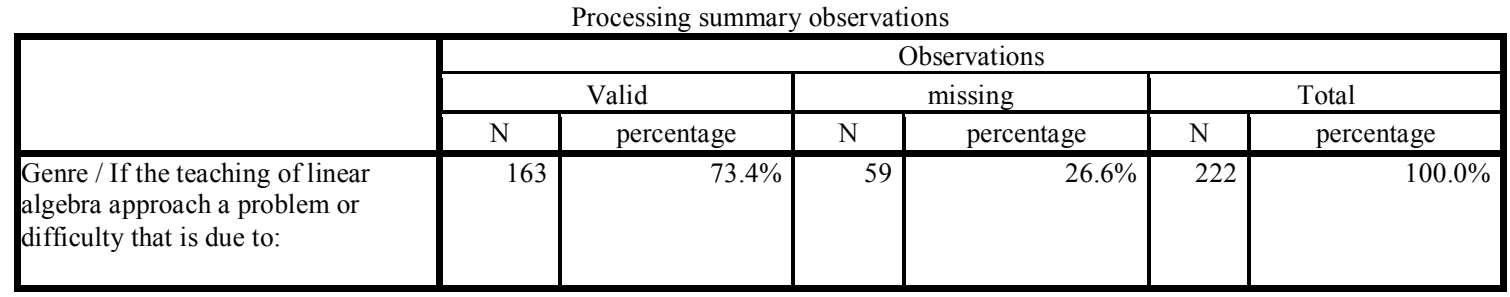

Genre / If the teaching of linear algebra approach a problem or difficulty that is due to

workforce

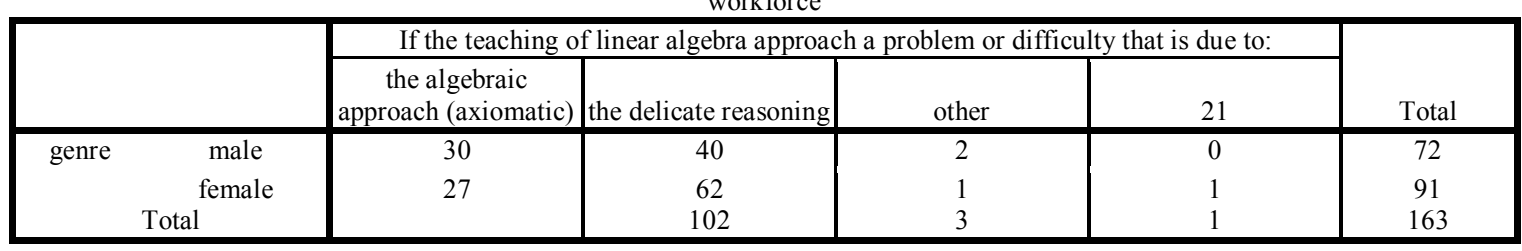




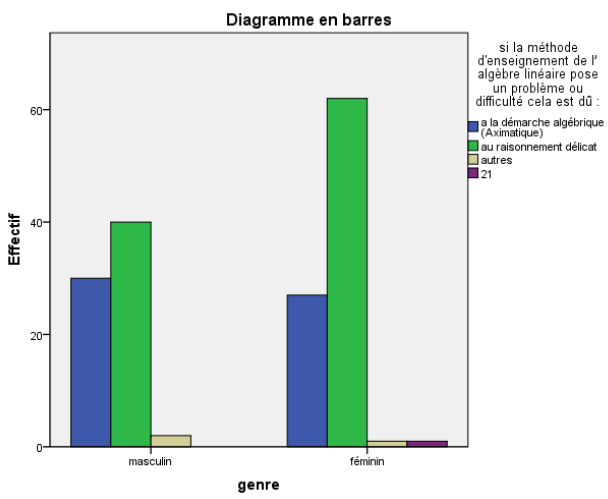

It has 163 students who have validated the two questions at the same time, a percentage of $73.40 \%$, which is majority, but we have 59 students who have not passed both questions is $26.60 \%$, this is a superior rate a quarter of the population sible, which is remarquabale.

Were 30 boys of 72 boys, or $41.67 \%$, and 27 girls of 91 girls is $29.67 \%$ believe that the teaching of linear algebra method poses a problem or obstacle, because of "the process algebraic (axiomatic). "The point made is that "the algebraic approach (Axiomatic) is an obstacle for boys more than girls.

And was 40 boys of 72 boys is $55.56 \%$ and 62 girls of 91 girls is $68.13 \%$ consider that the problems and difficulties for the method enseignenement are associated with "delicate reasoning."

The percentages of boys and girls are important, it reflects the mathematical raisonement in linear algebra presents a major obstacle for students, boys and girls, although the percentage of girls is higher than boys.

\section{8- Genre / Student, interested in linear algebra:}

\begin{tabular}{|c|c|c|c|c|c|c|}
\hline \multicolumn{7}{|c|}{$\begin{array}{l}\text { Processing summary observations } \\
\text { Observations }\end{array}$} \\
\hline & \multicolumn{2}{|c|}{ Valid } & \multicolumn{2}{|c|}{ missing } & \multicolumn{2}{|r|}{ Total } \\
\hline & $\mathrm{N}$ & percentage & $\mathrm{N}$ & percentage & $\mathrm{N}$ & percentage \\
\hline $\begin{array}{l}\text { Genre / Student, interested in } \\
\text { linear algebra: }\end{array}$ & 196 & $88.3 \%$ & 26 & $11.7 \%$ & 222 & $100.0 \%$ \\
\hline
\end{tabular}

Genre / Student, interested in linear algebra:

\begin{tabular}{|c|c|c|c|c|c|c|}
\hline & \multicolumn{5}{|c|}{ Student, interested in linear algebra: } & \multirow[b]{2}{*}{ Total } \\
\hline & yes & no & 3 & 4 & 5 & \\
\hline genre & 63 & 21 & 2 & 0 & 0 & 86 \\
\hline Total female & 71 & $\begin{array}{l}32 \\
53\end{array}$ & $\begin{array}{l}2 \\
4\end{array}$ & $\begin{array}{l}4 \\
4\end{array}$ & $\begin{array}{l}1 \\
1\end{array}$ & $\begin{array}{l}110 \\
196\end{array}$ \\
\hline
\end{tabular}

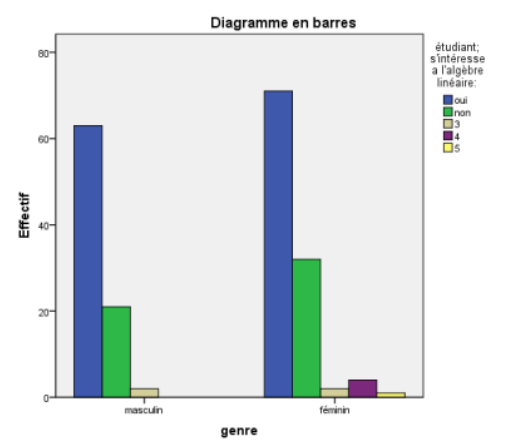

196 students who have validated the issues simultaneously, a rate of $88.30 \%$, which is very important, and only $11.70 \%$, which did not validate the two issues.

So we can make judgments thanks to this population.

Were 63 boys of 86 boys, or $73.26 \%$, and 71 girls of 110 girls, or $64.55 \%$ believe that the student is interested in linear algebra.

It is found that the student, boy or girl is interested in linear algebra, and that contrary to the opinion of the people. 
9- Genre / Do you prefer the presentation of the course is through:

Processing summary observations

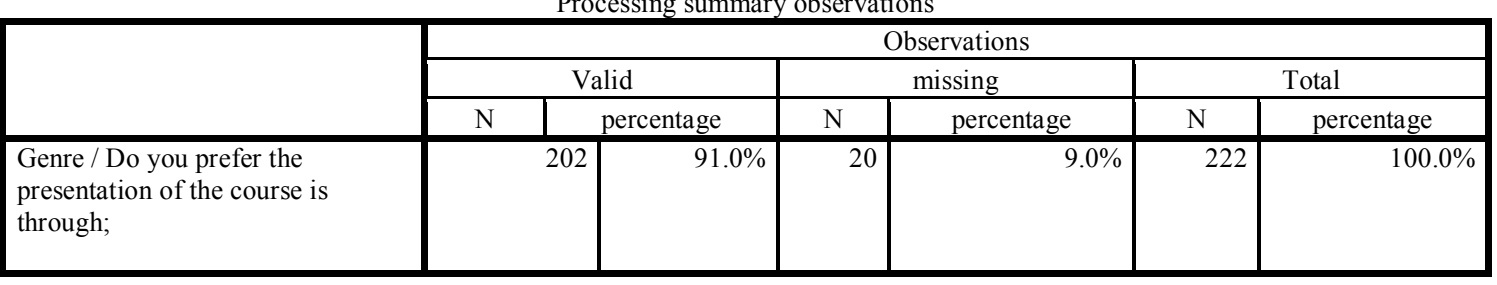

Genre / Do you prefer the presentation of the course is through;

workforce

\begin{tabular}{|cc|c|c|c|c|c|c|}
\hline & \multicolumn{6}{|c|}{ Do you prefer the presentation of the course is through; } & \\
\cline { 3 - 7 } & & data show & handout & given in Table & $\begin{array}{c}\text { a mixture of } \\
\text { methods }\end{array}$ & other & Total \\
\hline \multirow{2}{*}{ genre } & male & 14 & 8 & 33 & 35 & 0 & 90 \\
& 6 & 18 & 44 & 43 & 1 & 112 \\
& Total & 20 & 26 & 77 & 78 & 1 & 202 \\
\hline
\end{tabular}

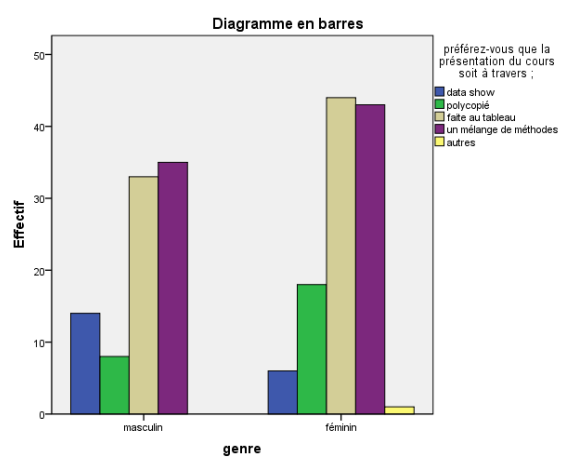

202 students, or $91.00 \%$, absolute majority who validated the two issues together.

Only 20 students who have not passed both questions.

There are 14 boys 90 boys or girls 6 and $15.56 \%$ of 112 girls, or $05.36 \%$ who prefer the presentation of the course through data show.

So we have to a minority of girls and boys.

We can say that the presentation data show is not acceptable by the students.

Similarly, we have 08 boys 90 boys, or $08.70 \%$, and 18 girls of 112 girls is $16.07 \%$, which prefer the presentation of the course through the handouts.

It also has the same remark is that the presentation of the course through the handouts are not acceptable by the students. There are 33 boys 90 boys, or $36.67 \%$, and 44 girls of 112 girls, or $38.39 \%$ prefer the presentation of the course is made on the board.

And almost the same result set for the last choice, that is to say $38.04 \%$ boys and $38.39 \%$ girls prefer the presentation is through "a combination of methods."

In short:

The presentation of the course, a data show, or handouts, is rejected by the students.

While that which is made to Table, or a mixture of methods are acceptable.

\section{0- Genre / Language does present an obstacle?}

Processing summary observations

\begin{tabular}{|c|c|c|c|c|c|c|}
\hline \multirow{2}{*}{} & \multicolumn{4}{|c|}{ Observations } \\
\cline { 2 - 7 } & \multicolumn{2}{|c|}{ Valid } & \multicolumn{3}{c|}{ missing } & \multicolumn{2}{c|}{ Total } \\
\cline { 2 - 7 } & $\mathrm{N}$ & percentage & $\mathrm{N}$ & percentage & $\mathrm{N}$ & percentage \\
\hline $\begin{array}{c}\text { Genre / Language does present an } \\
\text { obstacle? }\end{array}$ & 206 & $92.8 \%$ & 16 & $7.2 \%$ & 222 & $100.0 \%$ \\
\hline
\end{tabular}


Crosstab genre / language she presents an obstacle? workforce

\begin{tabular}{|ll|r|r|r|r|}
\hline & & \multicolumn{3}{|c|}{ language she presents an obstacle? } & \multicolumn{2}{|c|}{} \\
\cline { 3 - 6 } & & yes & no & 4 & \multicolumn{2}{|c|}{ Total } \\
\hline genre & male & 61 & 30 & 0 & 91 \\
& female & 64 & 50 & 1 & 115 \\
Total & & 125 & & 1 & 206 \\
\hline
\end{tabular}

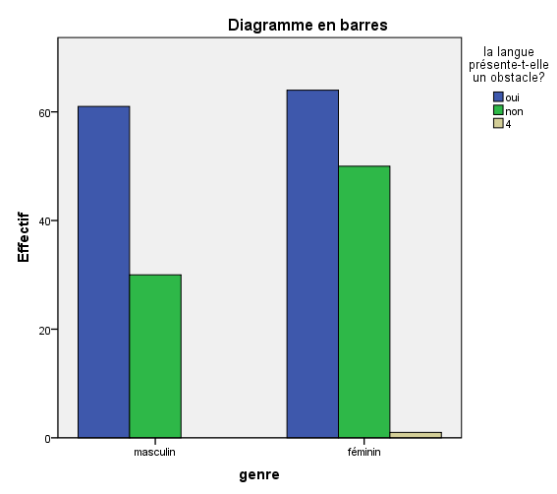

206 students, a rate of $92.80 \%$ who answered both questions at the same time and it is a majority.

We found 61 boys of 91 boys, or $67.03 \%$ believe that the French language has an obstacle, while 64 girls to 115 girls, or $55.65 \%$ believe that the French language is an ongoing challenge.

Although the percentage of boys is higher than girls, the French language is a barrier for majority-language students.

\section{1- Genre / If yes would you prefer a bilingual education (the French with Arabic explanation)?}

Processing summary observations

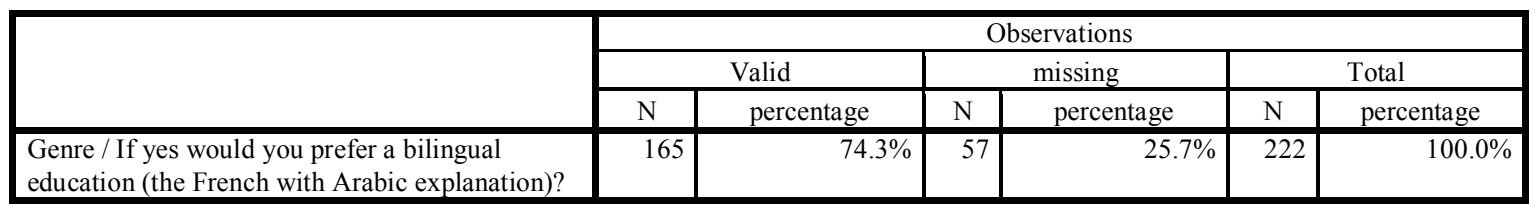

Crosstab genre / whether you prefer a bilingual education (in French with Arabic explanation)?

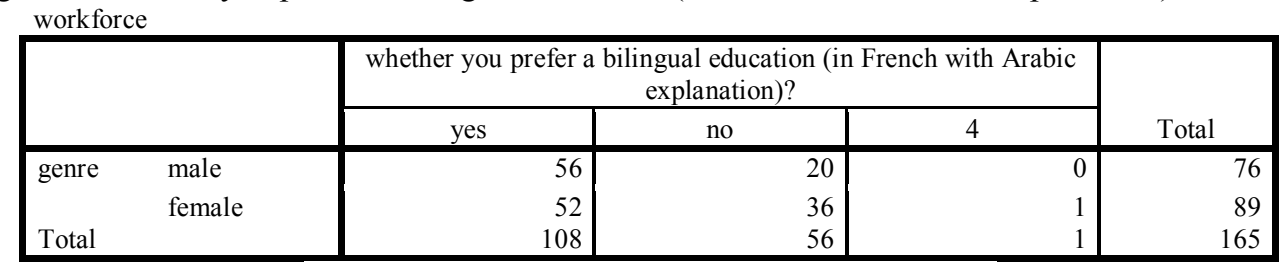

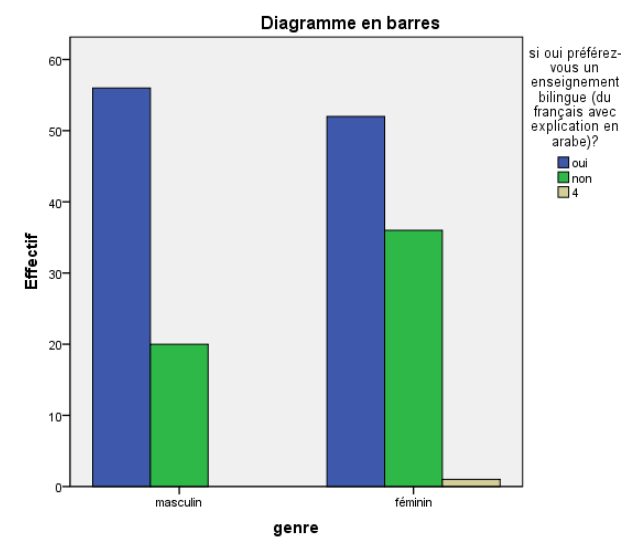


165 students, who validated the two questions at the same time, which represents a rate of $74.30 \%$ is a high rate, but it has 57 students who have not passed both questions, a rate of $2570 \%$, which remained outstanding, although a minority.

Were 56 boys of 76 boys is $73.68 \%$, and 52 girls of 89 girls, or $58.43 \%$, prefer a bilangue education (the French with Arabic explanation).

It is clear that the majority of the boys answered yes, but with a smaller rate than girls, and is also important.

The results found in this study are:

\section{Conclusionandresults:}

$>$ The girls outnumber boys.

$>$ The girls face more difficulties than boys in the industry Physics-Chemistry option.

> The boys high school math mastered better than girls.

The boys and girls who have their bachelor's degree in physics and chemistry have same percentage in the sample chosen

$>$ The girls face problems in linear algebra and difficulés levels of knowledge than boys, while boys encounter problems and difficulties in linear algebra "teaching methods" than girls.

$>$ The lack of prerequisites for boys has a major obstacle to girls.

$>$ The mathematical raisonement in linear algebra presents a major obstacle for students, boys and girls,

$>$ The boy or girl is interested in linear algebra.

$>$ The presentation of the course, a data show, or handouts, is rejected by the students While that which is made to Table, or a mixture of methods are acceptable.

$>$ The French language has a barrier for girls and boys, although the rate of boys is higher.

\section{References}

[1]. Brousseau, G. (1983) : Les obstacles épistémologiques et les problèmes en mathématiques, Recherches en Didactique des Mathématiques.

[2]. http://guy-brousseau.com/wp-content/uploads/2010/09/Les_obstacles_epistemologiques et la didactique des mathematiques89

[3]. Dorier, J.-L. \& al (1997).L'enseignement de l'algèbre linéaire en question. Grenoble, La Pensée Sauvage

[4]. Trigueros, M. \&Oktaç, A. (2005). La théorie APOS et l'enseignement de l'algèbre linéaire. Annales de Didactique et de Sciences Cognitives, Vol. X, 157-176.

[5]. Guy Brousseau Les obstacles épistemologiques etla didactique des mathématiques

[6]. CONFOBS2 1989 Page 1 sur 19 Tirage dimanche 19 mars 2000 